\title{
Studia
}

SYNCHRONICZNE I DIACHRONICZNE ASPEKTY BADAŃ POLSZCZYZNY

www.wnus.edu.pl/sj | DOI: 10.18276/sj.2020.19-04 | 51-65

\section{RENATA BIZIOR}

ORCID: 0000-0003-3216-4037

Uniwersytet Humanistyczno-Przyrodniczy, Częstochowa

r.bizior@autograf.pl

\section{Całuję nogi pańskie czy kończe francuskim stylem? \\ Uwarunkowania etykietalnych zachowań językowych w listach 2. połowy XVIII wieku (na materiale korespondencji Jędrzeja Kitowicza)}

\section{Słowa kluczowe}

etykieta epistolarna, etykieta językowa, grzeczność językowa, formuły etykietalne, list, Kitowicz

Keywords

epistolary etiquette, language etiquette, linguistic politeness, etiquette formulas, letter, Kitowicz

\section{Założenia wstępne}

List jako gatunek użytkowy jest zbiorem sformalizowanych reguł dookreślających sposoby konstruowania epistolarnego tekstu, reguł, które w okresach wcześniejszych ujmowane były w listownikach, mających istotne znaczenie normatywne do początku XIX wieku¹. Reguły te podlegały zmianom warunkowanym m.in. przez przeobrażenia kontekstu cywilizacyjnego, kulturowego i społecznego. Znacząca zależność od determinant zewnętrznych

1 Zob. Przemysława Matuszewska, „Listowniki polskie. Stan i perspektywy badań”, Pamiętnik Literacki 73 (1982), 3-4: 42. 
jest jedną ze zmiennych cech listu. Stefania Skwarczyńska² pisze, że w ewolucji gatunku widoczne jest oswabadzanie się z tych więzów, na co wskazują duże różnice pomiędzy listem w XVIII a XIX i XX wieku.

Najwyraźniejsze zmiany zachodzą w ramie kompozycyjnej listu złożonej z formuły inicjalnej i finalnej, które stanowią jego zasadnicze elementy konstrukcyjne. Tworzą ramę strukturalną wyznaczającą kształt listu, a także usytuowanie jego elementów składowych w linearnym porządku tekstu³, wypełnianą przez skonwencjonalizowane formuły etykietalne, które wraz z biegiem wieków petryfikują się lub rozluźniają, rozszerzają bądź upraszczają ${ }^{4}$. Przekształceniom podlega nie tylko ich formalna, językowa postać, ale również związane z nimi znaczenie pozajęzykowe. Znamienne dla przeszłości etykietalne zachowania językowe wciąż pozostają interesującym dla badań aspektem epistolarnych konwencji z uwagi na sposób ich formalnego ukształtowania, wariantywność oraz uwikłanie: pragmatyczne, socjologiczne i kulturowe.

Głównym celem prezentowanych badań jest omówienie zachowań etykietalnych utrwalonych w postaci formuł tworzących ramę finalną XVIII-wiecznych tekstów epistolarnych i rozpoznanie czynników ich zróżnicowania. Mimo że wykładniki etykiety językowej są składnikami trzech sformalizowanych segmentów strukturalnych listu: inskrypcji, formuły salutacyjnej oraz subskrypcji ${ }^{5}$, to w pracy uwagę koncentruję na ostatnim, końcowym segmencie listu ze względu na mniejszy zakres unormowań odnoszących się do tej części ramy kompozycyjnej. Formuły subskrypcyjne wieńczące tekst epistolarny są o tyle bardziej interesujące, że są poddane mniejszemu naciskowi normatywnemu, co sprzyja w większym stopniu - niż w przypadku początkowej części listu - wyrażeniu indywidualnych preferencji nadawcy. W tym miejscu struktury listu dopuszcza się przekraczanie gatunkowego formularza i nadawanie swoistego, indywidualnego nacechowania formułom grzecznościowym. Jak podaje Katarzyna Mroczek, „listowniki dużo mniej precyzyjnie opisują ten element niż inne elementy nagłówka i zakończenia, pozostawiając tutaj pewną swobodę piszącemu"6. Tego rodzaju okoliczności oferują możliwość wykorzystywania różnorodnych formuł etykietalnych.

\footnotetext{
2 Zob. Stefania Skwarczyńska, Teoria listu (Białystok: Wydawnictwo Uniwersytetu w Białymstoku, 2006), 269-270 i n.; pierwsze wydanie ukazało się we Lwowie w 1937 r. Na ten temat również Anna Kałkowska, Struktura składniowa listu (Wrocław: Zakład Narodowy im. Ossolińskich, 1982), 51-53.

3 Elżbieta Książek, Tekst epistolarny w świetle etykiety językowej (Kraków: Wydawnictwo Naukowe Akademii Pedagogicznej, 2008), 4.

4 Kałkowska, Struktura sktadniowa, 51-53.

5 Katarzyna Mroczek, „Tytulatura w korespondencji staropolskiej jako problem stosunku między nadawcą a odbiorcą", Pamiętnik Literacki 69 (1978), 2: 128.

6 Tamże, 140.
} 


\section{Listy Jędrzeja Kitowicza}

Impulsem do badań stało się wydanie niemal całej zachowanej epistolografii Jędrzeja Kitowicza $^{8}$ - autora Opisu obyczajów za panowania Augusta III - w 2017 roku w zbiorze Korespondencja i gazetki rękopiśmienne Jędrzeja Kitowicza z lat 1771-1776, przygotowane przez Tomasza Ciesielskiego, Sławomira Górzyńskiego i Filipa Wolańskiego9. Materiał do badań stanowią zatem listy jednego nadawcy pisane do kilku adresatów, z którymi nadawca pozostawał w określonych relacjach społecznych o niejednorodnym charakterze. W listach widzę teksty tworzone przez pisarza o określonej wrażliwości językowej i kompetencji stylistycznej. Pochodzą one z lat 1763-1801, z pogranicza doby średniopolskiej i nowopolskiej. Czas powstawania listów jest istotny z uwagi na zachodzące we wskazanych dziesięcioleciach przemiany komunikacyjne i kulturowe. Ich efektem była modyfikacja części tych norm gatunkowych, których przestrzeganie skutkowało znaczną szablonowością składników strukturalnych listu, w których istotne znaczenie miał określony kształt formuł etykietalnych. Nowe reguły - projektujące realizacje tekstowe - werbalizowane w listownikach ${ }^{10}$ deprecjonowały dawne spetryfikowane formuły grzecznościowe i dawały pierwszeństwo większej swobodzie i kreatywności językowej ${ }^{11}$. Z uwagi na zmiany zachodzące $w$ tym czasie w zakresie etykiety językowej istotny jest również wybór określonych konwencji epistolarnych przez autora Opisu obyczajów. Jest on tym bardziej ciekawy z tego względu, że Kitowicz to pisarz operujący językiem w sposób twórczy, kreatywny, co jest widoczne w stylistycznej organizacji jego prozy ${ }^{12}$.

Wobec tego celem szczegółowym artykułu jest odpowiedź na pytanie, na ile nadawca listów - pisarz tworzący w drugiej połowie XVIII wieku - ulegał presji konwencji komunikacyjnych i w jakim stopniu je przekraczał, a także w jakim stopniu swoje odzwierciedlenie znajdowały w tym procesie twórcze upodobania Kitowicza ${ }^{13}$. Zdaniem Stefanii

7 Publikacja nie zawiera wszystkich znanych listów pisarza, w zbiorze brakuje listu opublikowanego przez Agatę Demkowicz, „Nieznany list Jędrzeja Kitowicza przeciwko jezuitom”, Nasza Przeszłość 111 (2009): 293-311.

8 Źródła z XIX w. podają, że zbiór listów Kitowicza był bogatszy pod względem wielkości i bardziej zróżnicowany. Zob. Tadeusz Mikulski, „Do historii i źródeł Kitowicza”, Pamiętnik Literacki 44 (1953), 3-4: 29-72.

9 Tomasz Ciesielski, Sławomir Górzyński, Filip Wolański, red., Korespondencja i gazetki rękopiśmienne Jędrzeja Kitowicza z lat 1771-1776 (Warszawa: Wydawnictwo DiG, 2017).

10 Mowa tu o listowniku Stanisława Szymańskiego Wzory biletow, listow i memoryałow w rożnych materyach z przydatkiem uwag w powszechności o stylu listownym przypisków względem szczegulnych listów gatunkow i drobnych przestrog względem formalności w pisaniu, t. 1 (Warszawa: Drukarnia Po-Jezuicka, 1784), 18-20.

11 Anita Pawłowska, „Rola werbalnych formuł etykiety językowej w listach (na materiale z lat 17501860)”, Studia Językoznawcze. Synchroniczne i diachroniczne aspekty badań polszczyzny 12 (2013): 154 [153-163].

12 Renata Bizior, O języku prozy Jędrzeja Kitowicza (Częstochowa: Wydawnictwo Akademii im. Jana Długosza, 2012).

13 Skwarczyńska, Teoria listu, 270. 
Skwarczyńskiej w dziedzinie kompozycji epistolograficznej mieści się olbrzymie pole dla indywidualizmu twórcy, mimo formalnego skostnienia formy gatunkowej, potęgowanego przez konwencje epoki ${ }^{14}$.

Podstawową metodą stosowaną w postępowaniu badawczym jest analiza lingwistyczna środków językowych, zorientowana socjolingwistycznie, co pozwala na ukazanie związków zachowań językowych i społecznych uwarunkowań. Wykorzystane zostaną również narzędzia badawcze pragmatyki językowej i stylistyki.

\section{Etykieta epistolograficzna}

W odniesieniu do listu pojęcie etykiety (wzorca zachowania obowiązującego w określonej sytuacji i środowisku) ma szerszy zakres niż w wypadku innych form komunikacji, w związku z czym można mówić o etykiecie epistolograficznej. Elementy etykietalne stanowią szczególny, relewantny wyznacznik dawniejszych realizacji gatunkowych. W pierwszej kolejności należy wymienić zewnętrzną wobec tekstu etykietę listową, która nakazuje nie tylko określony tryb zapełniania papieru pismem, ale i składania go (podwójnie, poczwórnie) przed wysłaniem do adresata. W tym zakresie w XVIII wieku etykieta była dość sztywna - „wszystko wtedy, od złożenia papieru (w czwórkę) aż po miejsce na datę, miało swoje rygorystyczne normy"15. Drugim składnikiem etykietalnym jest epistolograficzna etykieta językowa przejawiająca się w wewnętrznej organizacji wypowiedzi listowej.

Definicje etykiety (grzeczności) językowej wykorzystywane w badaniach lingwistycznych odwołują się do propozycji Małgorzaty Marcjanik, która ujmuje ją jako zbiór przyjętych w danej społeczności wzorów językowych zachowań grzecznościowych, zwyczajowo przyporządkowanych określonym sytuacjom pragmatycznym ${ }^{16}$. Badaczka zaznacza, że w polskiej kulturze etykieta językowa opiera się na dwóch podstawowych zasadach: 1. okazywanie szacunku partnerowi dialogu z jednoczesnym umniejszaniem roli własnej osoby, 2. przejawianie zainteresowania sprawami ważnymi dla partnera komunikacji oraz jego rodziny ${ }^{17}$. M. Marcjanik pojęciem grzeczności językowej obejmuje wszystkie zachowania językowe, które są jednocześnie regulowane za pomocą norm językowych i obyczajowych ${ }^{18}$. Marek Cybulski, przyjmując to samo rozumienie etykiety językowej, proponuje

\footnotetext{
14 Tamże, 266.

15 Tamże, 295.

16 Na temat zależności etykiety językowej od wzorów kulturowych pisze Przemysław Kisiel, „Etykieta językowa a wzory kultury", Język a Kultura 6 (1992): 9-14.

17 Małgorzata Marcjanik, „Etykieta językowa”, w: Współczesny język polski, red. Jerzy Bartmiński (Lublin: Wydawnictwo Uniwersytetu Marii Curie-Skłodowskiej, 2001), 281.

18 Małgorzata Marcjanik, Polska grzeczność językowa (Kielce: Wydawnictwo Wyższej Szkoły Pedagogicznej im. Jana Kochanowskiego, 1997), 5.
} 
użycie terminu „obyczaj językowy” z uwagi na jego szerszy zakres ${ }^{19}$. Etykietę językową badacz ściśle wiąże z kodyfikacją, natomiast termin obyczaj językowy definiuje jako „zbiór ustalonych typów zachowań językowych, przyporządkowanych w danej grupie społecznej (kulturowej) określonym okolicznościom”, bez nacisku na łączność tych zachowań z normami.

Tekstowa obecność etykietalnych formuł inicjalnych i finalnych jako stałego i trwałego wyznacznika gatunkowego listu jest determinowana przez obowiązującą w danym czasie etykietę językową kształtowaną na podstawie określonych konwencji społeczno-kulturowych. W badaniach dawnej etykiety językowej listy stanowią nieocenione źródło jej poznania z uwagi na „obligatoryjne elementy gatunkowe związane ze specjalną etykietą epistolograficzną"20.

W pracach nad epistolografią zwraca się szczególną uwagę na socjolingwistyczne parametry wyboru językowych zachowań grzecznościowych, do których należą: relacja między nadawcą i odbiorcą (pełnione role społeczne, płeć i wiek) oraz typ kontaktu między partnerami dialogu (oficjalny, nieoficjalny) ${ }^{21}$. Za istotne uznać trzeba podejście Marii Wojtak $^{22}$ uwzględniające znaczenie relacji towarzysko-społecznych związanych z nakładaniem się komunikacyjnych ról nadawcy i odbiorcy, wyznaczników statusu społecznego oraz rangi towarzyskiej. Na kształt grzeczności językowej utrwalonej w XVIII-wiecznych listach miały wpływ również inne czynniki zwiększające stopień wariantywności form językowych.

\section{Finalne formuły etykietalne w listach Kitowicza}

Na budowę formuły etykietalnej zamykającej tekst oddziałują, oprócz konwencji gatunkowych i komunikacyjno-kulturowych: pragmatyczny wymiar tekstu epistolarnego, konstruowane akty mowy i zawarte w nich intencje, przewidywany efekt perlokucyjny, także dbałość o dalszą komunikację i relacje społeczne. List jest bowiem jednostką dialogu ${ }^{23}$ między korespondentami.

Charakter społecznej roli językowej i relacji między nadawcą a odbiorcą określa sytuacja społeczna. Status społeczny nadawcy i odbiorcy tekstu epistolarnego może być symetryczny bądź niesymetryczny, z kolei sytuacja towarzysząca korespondencji może

\footnotetext{
19 Marek Cybulski, Obyczaje językowe dawnych Polaków. Formuly werbalne w dobie średniopolskiej (Łódź: Wydawnictwo Uniwersytetu Łódzkiego, 2003), 3-4.

20 Tamże, 13.

21 Eugeniusz Tomiczek, System adresatywny języka polskiego i niemieckiego. Socjologiczne studium konfrontatywne (Wrocław: Wydawnictwo Uniwersytetu Wrocławskiego, 1983), 21 i n.

22 Maria Wojtak, „Staropolska etykieta językowa jako obraz relacji międzyludzkich (wybrane zagadnienia)", w: Przeszłość w językowym obrazie świata, red. Anna Pajdzińska, Piotr Krzyżanowski (Lublin: Wydawnictwo UMCS, 1999), 206-207.

23 Kałkowska, Struktura składniowa, 11.
} 
być: prywatna, półoficjalna, oficjalna; typ kontaktu: indywidualny, lokalny, ogólnonarodowy. Na aspekt formalny listu, zwłaszcza na formuły inicjalne i finalne, które są poddane rygorom etykiety językowej, a przy tym są silnie skonwencjonalizowane, oddziałuje przede wszystkim relacja nadawca-odbiorca ${ }^{24}$.

Prezentowana w listach Kitowicza odmienność relacji towarzysko-społecznych między nadawcą a odbiorcami pozwala na obserwację zróżnicowanych zachowań etykietalnych tworzących finalną ramę listów, sposobów ich różnicowania oraz stopnia wariantywności w listach danego obiegu nadawczo-odbiorczego bądź kilku obiegów. Z uwagi na adresatów korespondencji pisarza oraz relacje wiążące $\mathrm{z}$ nimi nadawcę, w zbiorze listów można wyróżnić następujące: prywatne, familijne (do siostry Ludwiki Makowskiej), oficjalne (do Michała Lipskiego, protektora Kitowicza), półoficjalne (do generałowej Józefy Zarembiny), oficjalne/półoficjalne (do księży: Snowadzkiego i Konopki, do urzędnika Lipskiego, Brodzyńskiego). Z uwagi na ograniczoną objętość pracy uwagę poświęcam nieoficjalnym listom do siostry nadawcy i oficjalnym do Michała Lipskiego. Listy do generałowej Zarembiny omówiłam w osobnym opracowaniu na podstawie rękopisów ${ }^{25}$.

\section{Kończę francuskim stylem - list do siostry Ludwiki Makowskiej}

Z korespondencji do starszej i jedynej siostry Ludwiki Makowskiej zachowały się zaledwie dwa listy, w tym jeden mający pełną strukturę, to on jest podstawą obserwacji. Jest to jeden $\mathrm{z}$ najbardziej interesujących tekstów z punktu widzenia etykiety, napisany w 1801 roku, zarazem jedyny zachowany list do rodziny i z tego powodu równie ważny. Dlatego też rozpatruję go w pierwszej kolejności. Znamienną cechą tego tekstu jest przełamanie standardu konwencji grzecznościowych, co jawi się jako konsekwencja niezbyt serdecznych w danym czasie relacji między rodzeństwem. Warto nadmienić, że formuła salutacyjna listu, która brzmi: Sercem najukochańsza Mościa Pani Siostro i Dobrodziejko (75)26, jest dość konwencjonalna jak na familijny obieg komunikacyjny. Poprzedza właściwy segment listu zbudowany zaledwie z trzech zdań, z których o pragmatyce tekstu decyduje pierwsze, będące pośrednim, ekspresywnym aktem mowy wyrażającym niezadowolenie nadawcy z przebiegu korespondencji (dialogu) z siostrą. Brzmi on następująco: Kiedy W.M. Pani Dobrodziejce przykre jest pisanie, to pewnie i czytanie, więc nie fatyguje jej dtugiem pismem [...] (75). Ów akt mowy jest reakcją na wcześniejszy list siostry do Kitowicza i - jako rodzaj repliki

\footnotetext{
24 Katarzyna Sicińska, Polszczyzna południowokresowa XVII i XVIII wieku (na podstawie epistolografii) (Łódź: Wydawnictwo Uniwersytetu Łódzkiego, 2013), 78; Anna Kałkowska, „Mówiona staropolszczyzna w zwierciadle listów", Poznańskie Spotkania Językoznawcze 7 (2001): 78.

25 Renata Bizior, „Z prywatnej korespondencji Jędrzeja Kitowicza - uwagi o cechach gatunkowych osiemnastowiecznego listu", Prace Naukowe AJD w Częstochowie. Językoznawstwo 8 (2012): 23-38.

26 Cyfry w nawiasach oznaczają numery stron epistolografii Jędrzeja Kitowicza, na których znajdują się analizowane zwroty.
} 
nacechowanej ekspresją negatywną - łamie konwencję grzecznościową listu. Dającą się zaobserwować ekspresywność listu, jego ograniczoną informatywność dopełnia obniżenie grzeczności językowej. Jego wyrazem jest szablonowa formuła zawierająca życzenia, po której następują niestandardowe elementy metatekstowe zamykające list (dla krótkości ten list kończę francuskim stylem) oraz formuła etykietalna neutralizująca zasadę okazywania szacunku partnerowi dialogu z jednoczesnym umniejszaniem roli własnej osoby. Ma ona postać obcego kulturowo wyrażenia etykietalnego, zapożyczonego z nowej (porewolucyjnej) francuskiej równościowej etykiety językowej. Jest to tym bardziej istotne, że Kitowicz pisze do siostry (niewiele starszej od siebie), łamiąc zasadę staropolskiego modelu grzeczności - okazywania szczególnego szacunku m.in. kobietom, osobom starszym²7. Wyraźnie zasygnalizowana w formule Pozdrowienie, braterstwo i uszanowanie ${ }^{28}$ równorzędność między partnerami dialogu pozostaje w sprzeczności z tradycyjnymi normami etykietalnymi. Przy kontakcie familiarnym możliwe jest odrzucenie określonej konwencji komunikacyjnej ${ }^{29}$, niemniej jednak w tym wypadku doszło do skrzyżowania familiarności z oschłą oficjalnością i swoistej gry komunikacyjnej. Dla zobrazowania zakresu naruszenia tradycyjnej konwencji epistolograficznej w liście z początku XIX wieku cytuję formułę finalną omawianego listu w całości:

\section{Życze jej jak najlepszego zdrowia i dla krótkości ten list kończę francuskim stylem. \\ Pozdrowienie, braterstwo i uszanowanie \\ Ks. Jędrzej Kitowicz (75)}

Wpływ języka francuskiego na etykietalną obudowę listu, jak podaje Anita Pawłowska ${ }^{30}$, można zaobserwować już w okresie oświecenia, kiedy to ogranicza się jednak do powitań bonjour/bonsoir, form tytularnych monsieur, madame itp. bądź kalk językowych zwrotów pożegnalnych: do widzenia, do zobaczenia (fr. au revoir).

W powyższym użyciu obcej kulturowo formy etykietalnej ujawniają się preferencje Kitowicza co do zasad grzeczności językowej, które ujawniają negatywne wartościowanie przez pisarza formuł przejmowanych z nowej francuskiej etykiety językowej. Tego rodzaju użycie pojawia się w listach jednokrotnie, w sytuacji pewnego konfliktu między nadawcą a odbiorcą, związanego z pogorszeniem się relacji między nimi jako aktorami dialogu.

\footnotetext{
27 Maria Wojtak, „Wybrane elementy staropolskiej etykiety językowej”, Język a Kultura 6 (1992): 34.

28 Podobną formułę grzecznościową o postaci Pozdrowienia i braterstwo, Lelewel, ewokującą model francuskiej etykiety porewolucyjnej, wykorzystuje Joachim Lelewel w liście datowanym w Paryżu w 1832 r. Zob. Zygmunt Kolankowski, „Z «lelewelianów» leningradzkich”, Z Historii Nauki i Techniki 3 (1958), 1: 142.

29 Halina Wiśniewska, „Zachowania grzecznościowe w listach rodzinnych Ignacego Krasickiego”, Pamiętnik Literacki 91 (2000), 3: 161.

30 Anita Pawłowska, „Wpływ zmian społecznych i kulturowych na etykietę językowa początków doby nowopolskiej”, Język a Kultura 26 (2019): 109.
} 
Na tej podstawie uznać można Kitowicza za zwolennika tradycyjnych formuł grzecznościowych, utrwalonych kulturowo w polszczyźnie.

Użycie krótkiej, nietradycyjnej zapożyczonej (lub stylizowanej na nią) formuły etykietalnej, mającej pod względem pragmatycznym negatywny wydźwięk illokucyjny, zostało zdeterminowane przez jakość aktualnej relacji rodzinnej, zaburzoną strukturę listu i zbiór illokucji o negatywnym potencjale ekspresywnym. Czynniki te powodują, że zastosowanej formuły nie można uznać za świadectwo nowoczesności etykiety, lecz za oryginalną, służącą zachowaniu pewnego poziomu językowej grzeczności.

\section{Całuję nogi pańskie - listy do Michała Lipskiego}

Korespondencja Kitowicza z Michałem Lipskim (z lat 70. XVIII w.), złożona z 31 listów właściwych ${ }^{31}$, mieści się w polu komunikacji oficjalnej, jej cechy językowe i strukturalne wyznacza przede wszystkim nierównorzędny status uczestników komunikacji. Nierównorzędność rang uczestników dialogu wynika z układu społecznego i kulturowej konwencji epoki. Lipski jest magnatem o znacznych wpływach politycznych, pełni ważne funkcje publiczne (opat lubiński, pisarz wielki koronny, referendarz wielki koronny, następnie sekretarz wielki koronny), jest przedstawicielem władzy, któremu zgodnie z wzorcami kulturowymi należy się szczególne dowartościowanie znajdujące wyraz w etykietalnej obudowie aktów mowy. Kitowicz jako nadawca sytuuje się w pozycji podrzędnej, również z tej racji, że przez wiele lat sprawował na dworze Lipskiego funkcję sekretarza.

Formuły etykietalne zamykające listy do Lipskiego różnią się diametralnie od adresowanych do siostry Kitowicza, wyrażają inny typ relacji towarzysko-społecznej i są nośnikiem wartości honoryfikatywnych, wobec czego są bardziej złożone pod względem formalnym i semantycznym, a także bardziej staranne pod względem stylistycznym.

W zgromadzonym zbiorze złożonym z trzydziestu formuł finalnych (jeden list nie ma zakończenia na skutek zmiany struktury na gazetową, nowinkarską), większość jest użyta jednokrotnie, tylko jedna z formuł została użyta dwa razy, co może świadczyć o znaczeniu formuły finalnej dla dalszej komunikacji. Wskazuje również na tendencję do unikania przez pisarza struktur silnie spetryfikowanych, a także na zakres możliwej wariantywności etykietalnych pożegnań. W listach, co prawda, Kitowicz wykorzystuje określone szablony etykietalne, ale stara się je wypełniać różnorodnymi środkami językowymi i różnicować akty etykiety językowej.

W subskrypcji każdego listu używana jest etykietalna formuła nominalno-atrybutywna z wbudowaną frazą wokatywną. Wysoki status społeczny adresata jest wyrażany i uwydatniany przez spetryfikowane, o wariantywnej postaci, formuły adresatywne,

31 W zbiorze korespondencji do Michała Lipskiego mieszczą się również tzw. listy-gazety, czyli gazety rękopiśmienne, które nie są właściwymi listami. 
wyzyskujące jeden podstawowy schemat składniowy. Ich funkcja polega również na projektowaniu stosunku odbiorcy tekstu do nadawcy ${ }^{32}$. Adresatywy mają strukturę składnikową złożoną z inicjałów frazy atrybutywnej o różnej długości (np. Jaśnie Wielmożny Wielce Miłościwy) i frazy nominalnej (Pan (i) Dobrodziej), np. J.W.W.M. Pana Dobrodzieja (82), J.W.M.W.M.W.M. Pana Dobrodzieja (212) lub ukształtowaną w inny sposób, np. Jaśnie Wielmożnego W.M.W.M. Pana Dobrodzieja (96). Nagromadzenie atrybutywnych określeń etykietalnych podkreśla hierarchicznie wyższą rangę odbiorcy i jest sygnałem honoryfikatywności. Omawiane frazy są modyfikowane wskutek rozszerzania o kolejne składniki atrybutywne, np. J.W.W.M.W.M. Pana i Najosobliwszego Dobrodzieja (94) lub redukowania elementów właściwych dla formuły podstawowej, np. Jaśnie Wielmożnego Pana i Dobrodzieja (312), Jaśnie Wielmożnego Pana Dobrodzieja (225), JW. Pana i Dobrodzieja (130), JW Pana Dobrodzieja (230), które używane są w dalszych latach korespondencji, co może wskazywać na pewną zmianę w jakości relacji społeczno-towarzyskiej między korespondentami.

W zakresie formuł werbalnych w ramie finalnej listów do Lipskiego dominuje szablon zawierający połączenie werbalno-nominalne całuję nogi pańskie, realizujące schemat całuję + biernik nazwy części ciała, który jest, zdaniem Anity Pawłowskiej ${ }^{33}$, w tym okresie (1750-1860) standardowym konwersacyjnym aktem powitalnym, natomiast w roli pożegnań jest słabo poświadczony w tekstach. Akty te wywodzą się z ceremonialnej formuły przeznaczonej dla monarchy (całuję rękę/stopy), z czasem były wykorzystywane w zwrotach adresowanych do odbiorcy o pozycji niepomiernie wyższej niż pozycja nadawcy ${ }^{34}$. Czynnik socjologiczny oraz sytuacyjny (oficjalność) determinują w głównej mierze użycia powyższej formuły. Te uwarunkowania formuły grzecznościowej są niezwykle wyraźne w korespondencji Kitowicza do Lipskiego. Formuliczny zwrot o pełnej postaci całuję nogi pańskie lub uproszczonej całuję nogi występuje w dwunastu formułach pożegnalnych, stanowiąc pierwszorzędny, dominujący składnik ramy finalnej w dziesięciu listach oraz drugorzędny w dwóch. Formuła całuję nogi jest pierwszorzędnym elementem aktu grzecznościowego m.in. w subskrypcjach, które podaję w całości, zaznaczając podział na wiersze:

Całujęnogi pańskie/JW. Pana i Dobrodzieja / najobowiąańszym i najniższym podnóżkiem (s. 130); Całuję nogi pańskie / Jaśnie Wielmożnego W.M.W.M. Pana Dobrodzieja / najniższy sługa i podnóżek (150); Całuję nogi pańskie niegodny podnóżek (259); Nieskończona wdzięczność za odebrane niezliczone dobrodziejstwa od / Jaśnie Wielmożnego Pana i Dobrodzieja, / którego nogi całuję wierny sługa i podnóżek (146).

W jednym przypadku zwrot ma postać rozszerzoną do catuję ręce i nogi: [...] od tego rąk Pańskich, które wraz i nogi całuję / JW Pana Dobrodzieja / nieskończenie obowiazany

\footnotetext{
32 Mroczek, „Tytulatura w korespondencji”, 130.

33 Anita Pawłowska, Formuly werbalne etykiety polskiej od połowy XVIII wieku do lat sześćdziesiatych XIX wieku. Analiza socjolingwistyczna (Łódź: Wydawnictwo Uniwersytetu Łódzkiego, 2014), 71.

34 Cybulski, Obyczaje językowe, 77-78.
} 
i najniższy stuga i podnóżek (230). Jej wykorzystanie wiąże się z użyciem w wypowiedzi kończącej list słowa ręce, co powoduje włączenie go do schematu z werbalnym całuję. Ciekawe rozszerzenie formuły o przysłówek pokornie nastąpiło we fragmencie J.W Pana pokornie nogi całuję (s. 289), który kończy, a nie rozpoczyna, formułę subskrypcyjną listu, w którym nadawca zawarł szereg ekspresywnych aktów podziękowań za przesłane dokumenty. Warto odnotować obecność specyficznej formuły otwierającej akt etykietalny i wyrażającej charakter układu towarzysko-społecznego łączącego nadawcę i odbiorcę, jaką jest fraza Teraz w ustawicznym tchnieniu szacunku i przywiazania jestem (289).

Wyraz nogi w wyrażeniu syntaktycznym do nóg jest ośrodkiem konstrukcji wzbogacających akty etykietalne o dodatkową ekspresję, używane one były w XVII wieku w wypowiedziach epistolarnych do osób zajmujących najwyższą pozycję społeczną ${ }^{35}$. W listach do Michała Lipskiego mają wymiar honoryfikatywny i pragmatyczny, podkreślają społeczny status i znaczenie odbiorcy; są to zwroty: rzucam się do nóg, ścielę się do nóg, upadam do nóg występujące w subskrypcjach: Sam do dalszych usług w prawdziwej ochocie rzucam się do nóg pańskich (128); Ja się już do nóg ścielę / Jaśnie Wielmożnego Pana i Dobrodzieja (122); Wysiadtszy z tej karety, upadam do nóg pańskich (240). Ostatni fragment jest swoistym zabiegiem stylistycznym potwierdzającym językową sprawność nadawcy.

Prezentowane sformułowania etykietalne są podporządkowane zasadzie wyrażenia szacunku odbiorcy listu i świadectwem jej rygorystycznego przestrzegania. Kolejna grupa aktów etykietalnych służy wyrażeniu sposobu widzenia siebie w relacji do odbiorcy i realizuje funkcję umniejszania własnej osoby przez nadawcę.

Obserwacja kształtu subskrypcji badanych tekstów uświadamia, że niezwykle ważnym, konstrukcyjnym elementem formuł grzecznościowych była grupa nominalna sługa i podnóżek podkreślająca niższą pozycję nadawcy, wykorzystana z zachowaniem tego szyku w dwudziestu listach, np. Jaśnie Wielmożnego Pana Dobrodzieja nieskończenie obowiązany stuga i najniższy podnóżek (240). Etykieta epistolarna dyktowała użycie połączenia sługa (i podnóżek) jako odpowiadającego adresatywowi Pan Dobrodziej, obligatoryjnie stosowanemu w subskrypcji listu ${ }^{36}$. W sześciu z nich używa się pojedynczego określenia podnóżek, obniżającego bardziej status nadawcy niż samodzielnie występujące określenie sługa, obecne w dwóch formułach, np. Najobowiązańszy i najniższy podnóżek (131); szczero życzliwy i najniższy sługa (289). Zgodnie z normą etykietalną XVIII wieku ${ }^{37}$ wymienione jednostki nominalne obudowywane są dodatkowymi określeniami wzmacniającymi ich znaczenie pragmatyczne, w tym superlatywami: najniższy, niegodny, $\dot{z} y c z l i w y$, najżyczliwszy, szczero życzliwy, prawdziwy, wierny, prawdziwie obowiazany, najprzywiazańszy, najobowiąańszy. Zaznaczyć trzeba, że określenia te tworzą całe grupy wyrazowe w rodzaju

35 Cybulski, Obyczaje językowe, 76.

36 Wojtak, „Staropolska etykieta”, 211.

37 Pawłowska, Formuly werbalne, 82. 
nieskończenie przywiązany najniższy, intensyfikujące wartość etykietalną formuł i wzmacniające ich emocjonalne znaczenie.

Ważnymi formułami w perspektywie utrwalania jakości relacji między korespondentami są połączenia tworzone z wyrazami zapewniającymi o przywiązaniu nadawcy tekstu do odbiorcy: addykcja, przywiąany, najprzywiąańszy, przywiąanie, np. Jako prawdziwy dozgonny z przywiązaniem usilnym i głębokim poważaniem (131) w liście zawierającym podziękowania za łaskawość Lipskiego; Jaśnie Wielmożnego W.M.W.M. Pana Dobrodzieja nieskończenie przywiązany najniższy stuga i podnóżek (225); Zostawam z nieskończona addykcja dozgonnym respektem (88); sam staję się nikczemnym lubo do zgonu życia przywiązanym [...] niegodnym stuga i podnóżkiem (113), a także: Nieodmiennie, dozgonnie i najprzywiązańszy / życzliwy stuga i podnóżek (109). Istotną rolę w tworzeniu finalnych aktów etykiety odgrywa jednostka językowa obowiązany, sygnalizująca zobowiązanie do odwdzięczenia się za otrzymane łaski, odsłużenia ich. Występuje często w połączeniach w rodzaju: Najobowiązańszy stuga i podnóżek (82); Prawdziwie obowiąany stuga i podnóżek (144); Najobowiazańszy, najżyczliwszy lubo niegodny sługa i podnóżek (125). Warto wreszcie poświęcić uwagę podpisowi (Ks Jędrzej Kitowicz, Ks J. Kitowicz, Ks. J.K.), który sygnalizuje określony status społeczny nadawcy.

Kolejnym zagadnieniem, poza jakością strukturalno-semantyczną formuł etykietalnych, ich pragmatyką i znaczeniem socjolingwistycznym, jest zauważalna w badanym materiale tendencja do intensyfikowania ich mocy illokucyjnej na skutek ilościowego rozbudowywania struktur podstawowych, unormowanych przez etykietę językową. Wieloskładnikowa kompozycja, wiążąca się z użyciem środków atrybutywnych oraz ich superlatywizacją, jest podporządkowana wzmacnianiu projektowanego oddziaływania na adresata. Zabiegi tego rodzaju podnosiły bowiem znacznie stopień językowej grzeczności oraz honoryfikatywności ${ }^{38}$. Podobną funkcję pełniło używanie różnorodnych wariantów formuł etykietalnych, dbałość o znikomą powtarzalność formuł, poszukiwanie nowych konfiguracji dla repertuaru środków etykietalnych, co wiązało się ze starannością językową i stanowiło wyraz grzeczności. Rozbudowane subskrypcje, zarówno w części poświęconej odbiorcy, jak i nadawcy, wykorzystywane były w celu uwydatnienia różnicy statusów społecznych nadawcy i odbiorcy na korzyść tego drugiego.

\section{Zakończenie}

Analiza finalnych segmentów listów Jędrzeja Kitowicza pisanych do możnowładcy Michała Lipskiego, zarazem protektora pisarza, oraz do siostry potwierdza wnioski badaczy wskazujące na mniejszy rygoryzm norm gatunkowych w odniesieniu do kształtu formuł subskrypcyjnych oraz możliwość ich indywidualnego nacechowania. Wskazuje również na

38 Cybulski, Obyczaje językowe, 248-249. 
oddziaływanie tendencji do rozluźniania epistolarnych norm gatunkowych, które było właściwe dla drugiej połowy XVIII wieku. Znikomy stopień reprodukcji tych samych aktów etykietalnych, dbałość o ich kształt estetyczny i walor pragmatyczny idą w parze z twórczym zmysłem językowym i stylistycznym ich nadawcy, który z oczywistych względów respektuje kulturowe normy etykietalne i splatającą się z nimi etykietę epistolarną. Kitowicz stara się, unikając jednorodnych formuł i tworząc różnorodne warianty, o przełamanie ich szablonowości. W analizowanym materiale uwagę zwraca sposób przekroczenia norm etykietalnych, zaobserwowany w korespondencji z najbliższą osobą (siostrą), z którą nadawcę wiąże zażyła osobista relacja. Nadawca zamyka list zaskakującą formułą: kończe francuskim stylem / Pozdrowienie, braterstwo i uszanowanie, która jest uwarunkowana ekspresywną illokucją całego listu, jego ograniczoną strukturą oraz zewnętrznymi czynnikami pragmatycznymi. W innych listach pisarza, również w tych, których analizy tu nie przedstawiono, cechujących się półoficjalnością i oficjalnością, do przełamania norm epistolarnej etykiety nie dochodzi. Pisarz respektuje normy gatunkowe, narzucające określone schematy kompozycyjne i etykietalne.

W listach do swojego protektora Michała Lipskiego Kitowicz przestrzega norm etykietalnych, a formuły finalne dostosowuje do łączącej korespondentów relacji formalno-społecznej. Pisarz unika formuł spetryfikowanych, różnicując akty etykiety językowej. Dba o zachowanie wykładników honoryfikatywności, nadając im pełną postać, np. J.W.W.M.W.M. Pana i Najosobliwszego Dobrodzieja lub skróconą JW. Pana i Dobrodzieja w zależności od pragmatyki danego tekstu. W zakresie formuł werbalnych nadawca wykorzystuje schematy: całuje nogi (pańskie), rzucam się do nóg, ściele się do nóg, upadam do nóg, rozbudowując je o dodatkowe jednostki językowe, podkreślające niesymetryczność relacji towarzysko-społecznej i komunikacyjnej. Uwypukleniu relacji służą określenia obniżające rangę nadawcy tekstu, w rodzaju stuga i podnóżek, podnóżek bądź sługa. Dopełniane są jednostkami nominalnymi wzmacniającymi pragmatykę wypowiedzi, takimi jak: najniższy, niegodny, wierny, najżyczliwszy. Formuła finalna listów Kitowicza do Lipskiego służy również wyrażeniu przywiązania i zapewnieniu o nim, służą temu środki językowe: rodzime - przywiązanie, najprzywiązańszy, przywiąany i obce-addykcja. Zróżnicowanie etykietalnych formuł językowych w subskrypcji listu, staranność w ich doborze, dbałość o kształt stylistyczny uznać trzeba za przejaw grzeczności językowej, umacniającej relację między nadawcą a odbiorcą listów. 


\section{Bibliografia}

\section{Źródła}

Tomasz Ciesielski, Sławomir Górzyński, Filip Wolański, red. Korespondencja i gazetki rękopiśmienne Jędrzeja Kitowicza z lat 1771-1776. Warszawa: Wydawnictwo DiG, 2017.

Bizior, Renata. O języku prozy Jędrzeja Kitowicza. Częstochowa: Wydawnictwo Akademii im. Jana Długosza, 2012.

Bizior, Renata. „Z prywatnej korespondencji Jędrzeja Kitowicza - uwagi o cechach gatunkowych osiemnastowiecznego listu". Prace Naukowe AJD w Częstochowie. Językoznawstwo 8 (2012): 23-38.

Cybulski, Marek. Obyczaje językowe dawnych Polaków. Formuly werbalne w dobie średniopolskiej. Łódź: Wydawnictwo Uniwersytetu Łódzkiego, 2003.

Demkowicz, Agata. „Nieznany list Jędrzeja Kitowicza przeciwko jezuitom”. Nasza Przeszłość 111 (2009): 293-311.

Kałkowska, Anna, „Mówiona staropolszczyzna w zwierciadle listów”. Poznańskie Spotkania Językoznawcze 7 (2001): 77-85.

Kałkowska, Anna. Struktura składniowa listu. Wrocław: Zakład Narodowy im. Ossolińskich, 1982.

Kisiel, Przemysław. „Etykieta językowa a wzory kultury”. Język a Kultura 6 (1992): 9-14.

Kolankowski, Zygmunt. „Z «lelewelianów» leningradzkich”. Z Historii Nauki i Techniki 3 (1958), 1: 141158.

Książek, Elżbieta. Tekst epistolarny w świetle etykiety językowej. Kraków: Wydawnictwo Naukowe Akademii Pedagogicznej, 2008.

Marcjanik, Małgorzata, „Etykieta językowa”. W: Współczesny język polski, red. Jerzy Bartmiński, 281291. Lublin: Wydawnictwo Uniwersytetu Marii Curie-Skłodowskiej, 2001.

Marcjanik, Małgorzata. Polska grzecznośćjęzykowa. Kielce: Wydawnictwo Wyższej Szkoły Pedagogicznej im. Jana Kochanowskiego, 1997.

Matuszewska, Przemysława. „Listowniki polskie. Stan i perspektywy badań”. Pamiętnik Literacki 73 (1982), 3-4: 41-53.

Mikulski, Tadeusz. „Do historii i źródeł Kitowicza”. Pamiętnik Literacki 44 (1953), 3-4: 29-72.

Mroczek, Katarzyna. „Tytulatura w korespondencji staropolskiej jako problem stosunku między nadawcą a odbiorcą". Pamiętnik Literacki 2 (1978): 127-148.

Pawłowska, Anita. Formuly werbalne etykiety polskiej od połowy XVIII wieku do lat sześśdziesiatych XIX wieku. Analiza socjolingwistyczna. Łódź: Wydawnictwo Uniwersytetu Łódzkiego, 2014.

Pawłowska, Anita. „Rola werbalnych formuł etykiety językowej w listach (na materiale z lat 1750-1860)”. Studia Językoznawcze. Synchroniczne i diachroniczne aspekty badań polszczyzny 12 (2013): 153-163.

Pawłowska, Anita. „Wpływ zmian społecznych i kulturowych na etykietę językowa początków doby nowopolskiej". Język a Kultura 26 (2019): 107-117.

Sicińska, Katarzyna. Polszczyzna poludniowokresowa XVII i XVIII wieku (na podstawie epistolografii). Łódź: Wydawnictwo Uniwersytetu Łódzkiego, 2013.

Skwarczyńska, Stefania. Teoria listu. Białystok: Wydawnictwo Uniwersytetu w Białymstoku, 2006.

Szymański, S. Wzory biletow, listow i memoryałow w rożnych materyach z przydatkiem uwag w powszechności o stylu listownym przypisków względem szczegulnych listów gatunkow i drobnych przestrog względem formalności w pisaniu. T. 1. Warszawa: Drukarnia Po-Jezuicka, 1784. 
Tomiczek, Eugeniusz. System adresatywny języka polskiego i niemieckiego. Socjologiczne studium konfrontatywne. Wrocław: Wydawnictwo Uniwersytetu Wrocławskiego, 1983.

Wiśniewska, Halina. „Zachowania grzecznościowe w listach rodzinnych Ignacego Krasickiego”. Pamiętnik Literacki 91 (2000), 3: 161-176.

Wojtak, Maria. „Wybrane elementy staropolskiej etykiety językowej”. Język a Kultura 6 (1992): 33-40.

Wojtak, Maria. „Staropolska etykieta językowa jako obraz relacji międzyludzkich (wybrane zagadnienia)”. W: Przeszłość w językowym obrazie świata, red. Anna Pajdzińska, Piotr Krzyżanowski, 205-216. Lublin: Wydawnictwo UMCS, 1999.

Całuję nogi pańskie czy kończe francuskim stylem? Uwarunkowania etykietalnych zachowań językowych w listach 2. połowy XVIII wieku (na materiale korespondencji Jędrzeja Kitowicza)

Streszczenie

W artykule omawia się rożne aspekty stosowania dawnej etykiety językowej (grzeczności językowej) w osiemnastowiecznych listach autorstwa Jędrzeja Kitowicza (1728-1804), twórcy Opisu obyczajów za panowania Augusta III. Pisarz znany jest również jako autor zbioru listów do osób, z którymi był związany różnymi relacjami społecznymi. Przedmiotem analizy są sposoby organizacji formuł etykiety językowej wykorzystywanych w finalnym segmencie listów, w którym normy gatunkowe dopuszczają pewien zakres twórczej indywidualności. Badania koncentrują się na związku między użyciami języka a społecznymi determinantami statusu nadawcy i odbiorcy. Artykuł omawia czynniki: socjolingwistyczne, pragmatyczne, genologiczne determinujące wybór odpowiednich formuł językowych. Omawia również strukturę i wariantywność formuł etykietalnych używanych w listach do siostry Kitowicza i możnego protektora Michała Lipskiego, u którego pracował jako sekretarz i dziennikarz. Zróżnicowanie etykietalnych formuł językowych w subskrypcji listu, dbałość o ich stylistyczne ukształtowanie uznaje się w artykule za przejaw grzeczności językowej, podtrzymującej określoną relację między nadawcą a odbiorcą listów.

"I am kissing your feet, Sir" or "I finish in a French style"? Determinants of ceremonial linguistic behaviour in letters of the second half of the 18th century (based on correspondence of Jędrzej Kitowicz)

\section{Su m mary}

This article discusses various aspect of using old Polish language etiquette (linguistic politeness) in the 18th-century letters written by Jędrzej Kitowicz (1728-1804), a well known author of Custom and Culture in Poland Under the Last Saxon King (translated by Oscar E. Swan, 2016, 2018). The writer is also known as the author of many letters to people connected with him by various social relations. The subject matter of this article encompasses ways of organizing the etiquette formulas used in the construction of the final part of the letters, where the genre norms allow for some creative individuality. The analysis is focused on relation between ways of using language and social determinants of the sender's and recipient's status. The paper 
discusses factors (sociolinguistic, pragmatic, genre) determining the selection of appropriate language formulas. It also presents the structure of etiquette formulas used in the letters to Kitowicz's sister and to his powerful protector Michał Lipski, for whom he worked as a secretary and newsman. The differentiation of language etiquette. The differentiation of language etiquette formulas in the letter subscription, the care for their stylistic shape, is recognized in this article as a manifestation of linguistic politeness, which serves to maintain specific relationship between the sender and the recipient of the letters.

Cytowanie

Bizior, Renata. „Całuję nogi pańskie czy kończę francuskim stylem? Uwarunkowania etykietalnych zachowań językowych w listach 2. połowy XVIII wieku (na materiale korespondencji Jędrzeja Kitowicza”. Studia Językoznawcze. Synchroniczne i diachroniczne aspekty badań polszczyzny 19 (2020): 51-65. DOI: 10.18276/sj.2020.19-04. 